\title{
The Visualities and Aesthetics of Prosecuting Aged Defendants
}

\author{
Mark Drumbl \\ School of Law, Washington and Lee University, Lexington, VA 2445o, USA \\ drumblm@wlu.edu \\ Caroline Fournet \\ Law School, University of Exeter, Amory Building, Rennes Drive, Exeter \\ $\mathrm{EX}_{4} 4 \mathrm{RJ}, \mathrm{UK}$ \\ c.i.fournet2@exeter.ac.uk
}

\begin{abstract}
The prosecution - whether domestic or international - of international crimes and atrocities may implicate extremely aged defendants. Much has been written about the legalisms that inhere (or not) in trying these barely alive individuals. Very little however has been written about the aesthetics the barely alive encrust into the architecture of courtrooms, the optics these defendants suffuse into the trial process, and the expressive value of punishing them. This is what we seek to do in this project.
\end{abstract}

\section{Keywords}

aged defendants - aesthetics of prosecution - visualities of prosecution

\section{Introduction}

Prosecutions of international crimes and atrocities interstitially find themselves swaying between two worlds - the world of the living and that of the dead - within the straddling space of the fading. ${ }^{1}$ How to imagine this space?

1 The authors would like to express their gratitude to the ECCC Media Center for their authorization to reproduce some pictures of defendants featured on the ECCC website as well as to David Hockney, Inc. for granting permission to reproduce one of the artist's paintings. 
What words to use to describe it? Should the words of the living be used - the vocabularies of law, of process, of evidence? Should the nether words of the necropolis be invoked - the words of memorialization, of preservation, of the archive, of respect for the dead, of the deceased body? Or both?

In order to address these questions, we welcomed contributions for a special issue of the International Criminal Law Review devoted to the visualities and aesthetics of putting very aged defendants on trial for atrocity. While we encouraged submissions from within law, we also hoped to receive contributions from authors with a variety of backgrounds (for instance: anthropology, sociology, criminology, museology, forensics) working in the fields of international criminal justice and transitional justice in a diverse array of jurisdictions. And we did receive proposals, in abundance. Proposals addressing broader questions of time, circularity, life cycles, and chronology also were welcome. And, happily, these too were received and the diversity of content was remarkable. The sequencing of the papers in this special issue reflects this variety of approaches and reflections. Starting with contributions that offer broader theoretical analyses, the special issue then goes into a set of different case studies and takes us on a journey through time periods and places, from courtrooms to spaces of memorialization.

Equally remarkable is the geographical spread of the contributions which explore widely different judicial and jurisdictional contexts: international, regional and domestic. If some contributions (notably by Samuel Matsiko and Caroline Davidson) address age as a cultural notion, whose evaluation may vary from one region to the next, the cartography of the contributions goes to show one thing: the issue of prosecuting very aged defendants is a global one. This is perhaps an aspect we hadn't quite envisaged when our serendipitous journey began unexpectedly at the International Association of Genocide Scholars Conference held in 2019 in Phnom Penh, Cambodia. It was a visit to the Extraordinary Chambers in the Courts of Cambodia (ECCC), on a hot July day, that sparked it all.

2

\section{The Scenery of Rhythmic Convalescence: The ECCC as a Judicialized Infirmary ${ }^{2}$}

The ECCC was established pursuant to an agreement adopted between the United Nations and the Government of Cambodia. The ECCC prosecutes senior

The authors thank all the contributors for their verve, energy, and insights; appreciations are due to Barbora Holá for her comments on this introduction.

2 This section is an updated version of a Blogtext we wrote and published as: 'The Judicialized Infirmary: The Aesthetics of Prosecuting the Barely Alive', Guest Post, Legal Sightseeing ECCC Phnom Penh, Legal Sightseeing, available online at https://legalsightseeing.org/2019/10/21/ guest-post-judicialized-infirmary-legal-sightseeing-phnom-penh/ (accessed 24 July 2021). 
leaders of the Khmer Rouge regime for grievous crimes that had been committed during its reign of terror, namely, between 6 April 1975 and 6 January 1979. Two million Cambodians perished during these dreadful years from murder, forced labor, and starvation. A People's Revolutionary Tribunal set up in 1979 by the replacement Cambodian government convicted Pol Pot, the top leader of the Khmer Rouge (Brother No. 1), in absentia after five days of proceedings and sentenced him to death. The sentence was never officially carried out. Pol Pot died in 1998 while under house arrest, ostensibly from heart failure but possibly from suicide. Stéphanie Benzaquen-Gautier's contribution to our symposium unwinds Pol Pot's trial, and exposes the body of Pol Pot, and hence forms a fascinating parallel at the national level to the work of the ECCC in proceedings that strayed far from legalism(s).

And shortly after our visit, on 4 August 2019, Nuon Chea (Figure 1) - the Khmer Rouge's chief ideologist - passed away in Phnom Penh's Khmer-Soviet Friendship Hospital. He was 93. Nuon Chea had been convicted-twice, in fact - by the ECCC. In Case oo1/o2, the ECCC first convicted him of war crimes and crimes against humanity and sentenced him to life imprisonment. At the time, 7 August 2014, he was 88 years old. Following another separate trial (Case oo2/o2), the ECCC additionally convicted him of genocide, crimes against humanity and grave breaches of the 1949 Geneva Conventions. Following these proceedings, Nuon Chea received a second life sentence on 16 November 2018. Initially placed under provisional detention on 19 November 2007, he had therefore been incarcerated since the age of 81 .

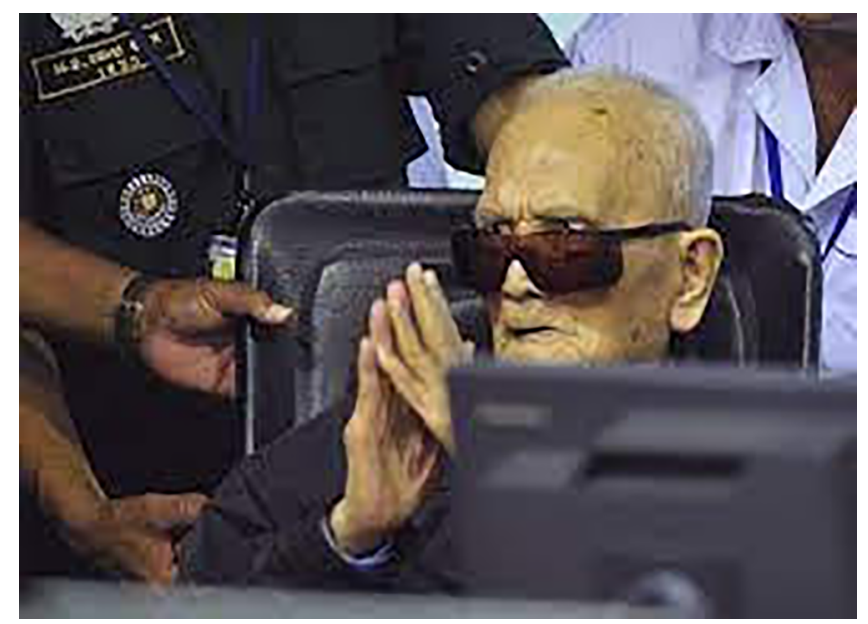

FIGURE 1 Nuon Chea. Photo credit: ECCC. 


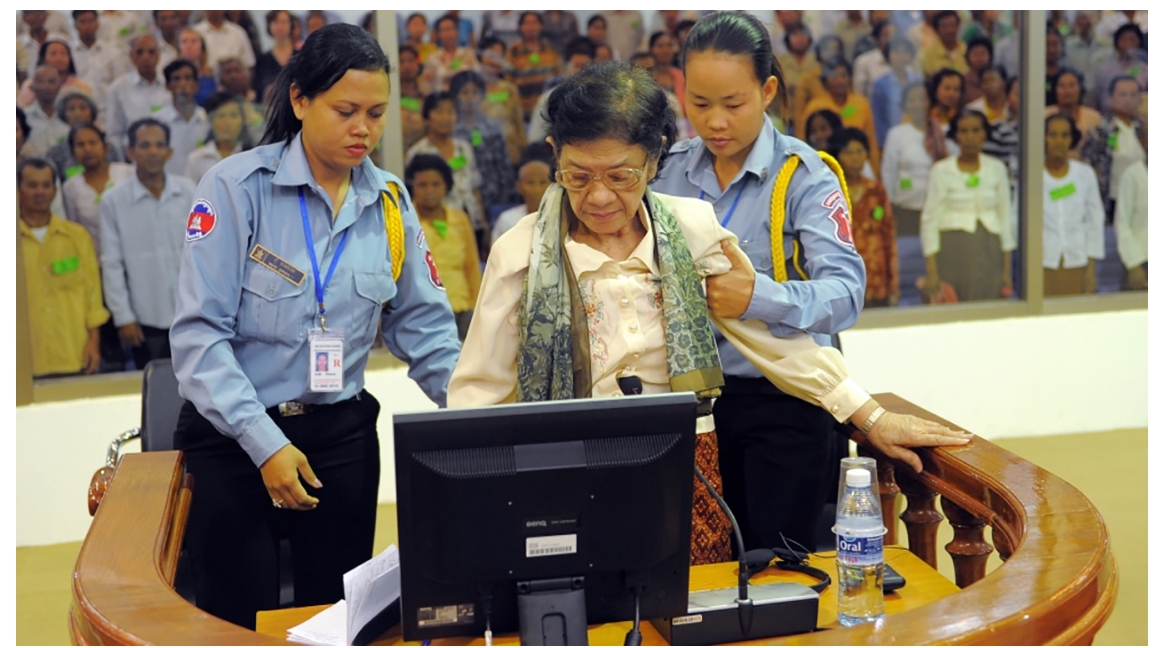

FIGURE 2 Ieng Thirith. Photo credit: EccC.

A year later, on 2 September 2020, Kaing Guek Eav, alias Duch, former commandant of the notorious S-21 torture center and a subordinate to Nuon Chea, died, also at the Khmer-Soviet Friendship Hospital, at the age of 77 . He had been serving a life sentence in the Kandal provincial prison in Cambodia since 2012. ${ }^{3}$

Nuon Chea was among the oldest of the Eccc detainees. But he was not at all exceptional in this regard. Ieng Sary-the Khmer Rouge's foreign minister - was born on 24 October 1925 and died while in detention on 14 March 2013. Ieng Sary-like Pol Pot—had been convicted in 1979 by the People's Revolutionary Tribunal. His wife Ieng Thirith (Figure 2) was found by the ECCC to be unfit to stand trial due to dementia. Released by a unanimous decision of the ECCC Trial Chamber on 13 September 2012, at the age of 8o, she remained under judicial supervision until her death three years later. Ieng Thirith had served as the former minister of social affairs.

Khieu Samphan (Figure 3), tried and convicted alongside Nuon Chea in Cases 002/01 and 002/02, and twice sentenced to life imprisonment, still lives. Born on 28 July 1931, he became the Khmer Rouge's head of state. When sentenced for the second time, in 2018, Khieu Samphan was asked to stand to hear the verdict. He obliged. In order to participate in this rite of the trial process, however, Alex Hinton reports that two guards had to prop him up, one

3 BBC, 'Cambodia genocide: Khmer Rouge prison chief Comrade Duch dies', 2 September 2020, available online at https://www.bbc.com/news/world-asia-53994189 (accessed 24 July 2021). 


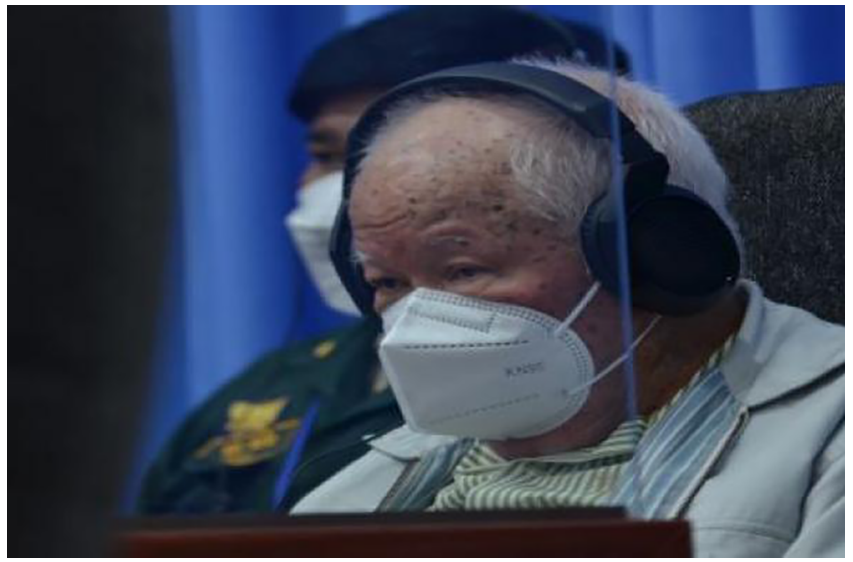

FIGURE 3 Khieu Samphan. Photo credit: ECCC.

of whom by hoisting the back of his trousers. ${ }^{4}$ Having appealed his sentence, Khieu Samphan was again present in court in August 2021; this time wearing a facemask as required by the sanitary conditions generated by the CovID-19 pandemic. ${ }^{5}$ So now the visual deepens, with sudden ubiquity it seems, another layer of life and death, pox and pestilence, frailty and shielding, medicalized expertise-each and all pervading the courtroom.

In her reflection on 'Negative Aesthetic Experiences of Prosecuting the Barely Alive', Shannon Fyfe also reports that Nuon Chea necessitated similar assistance to sit down and stand up. Paradoxically yet identically, the same human scaffolding had to happen in Pol Pot's 1998 trial—he too could only stand straddled by two guards as flying buttresses else he, too, would have crumbled. And what would that have 'looked like' if that had happened, if there were no flying buttresses supporting the ritual of the trial? What would it have looked like if a defendant collapsed under the weight of his own age and could not get up again while facing his judge and jury?

To hear the second verdict in Case 002/o2, Khieu Samphan arrived at the ECCC in a van. Nuon Chea came by ambulance. The court building assuredly was ready for them. Like many international courts, the ECCC operates, in terms of infrastructure, in a repurposed building. This building is sited roughly 16 kilometers west of Phnom Penh. Before becoming an international court,

4 A. Hinton, 'Justice at last', Mekong Review, November 2018, available online at https:// mekongreview.com/justice-at-last/ (accessed 24 July 2021).

5 See Eccc, 'Final Timetable for the Appeal Hearing in Case oo2/o2', available online at https:// eccc.gov.kh/sites/default/files/documents/courtdoc/\%5Bdate-in-tz\%5D/F66.1_EN.pdf (accessed 17 August 2021). 
the ECCC physical plant hosted the Royal Cambodian Armed Forces High Command Headquarters. The Khmer Rouge had seized that building and repurposed it, too, during the Democratic Kampuchea years. The Khmer Rouge after all annexed many buildings. S-21 had been a school prior to becoming a torture site. This is one reason why its floor tiles are bright and patterned, in a captivating shade of ochre, and why it has windows, balustrades and breezeways.

The ECcC indeed feels repurposed - as it is — yet with one notable (at times innovative) architectural twist. This twist involves all the medicalities fitted and engineered for the defendants. To be sure, many international courts have medical components to them, some of which are used: indeed, pace Milošević. But at the ECCC the medicality tips into rhythmic convalescence. The ECCC's medicalities moreover appear all-the-more juxtapositionally glaring in light of the parlous state of public health provision in Cambodia. And the transition of a detention facility into a hospice is not only the case in Phnom Penh, it also is so at Guantánamo Bay, where after decades inmates now receive nursing home care as they await trials that just do not seem to be robustly happening. ${ }^{6}$

The official tour of the ECCC, at least the tour that we took in July 2019, began as it should at an entrance. An ambulance parks there, protected under a curved awning that shelters it from sun and rain. Perhaps it was the one that had brought Nuon Chea. Or perhaps not. In any event, the guide opened the tour with the ambulance. He stated the obvious, namely, that it parks there in case something happens to a defendant—not a security issue, no, but in case a defendant falls ill or falls down. Having the ambulance there, well, it makes it safer, so it seems, to prosecute a defendant who totters and teeters between life and death. From the ambulance, the guide gestured to the right, as one faces the curved tunnel of the entrance, where he pointed out a holding cell. From the outside, it all looks quite austere and foreboding: a stark windowless door with an adjacent window perpendicularly to the right. The guide did not show the inside, but he spoke of it. Inside, according to his words, is a video feed, a monitor, and a bed. The holding cell was for the defendants, the barely alive (or living dead), ${ }^{7}$ who could retire there should their presence in the courtroom

6 C.l Rosenberg, 'Guantánamo Bay as Nursing Home: Military Envisions Hospice Care as Terrorism Suspects Age', New York Times (27 April 2019), available online at https://www. nytimes.com/2019/o4/27/us/politics/guantanamo-bay-aging-terrorism-suspects-medical-care. html (accessed 24 July 2021).

7 We generally opt for the 'barely alive' term, the 'living dead' being mostly used to qualify atrocities themselves. See, e.g., A. Applebaum, Gulag: A History (Doubleday, New York, NY, 2002), pp. 224-225: 'throughout the Gulag's existence, the prisoners always reserved a place at the very bottom of the camp hierarchy for the dying — or rather, for the living dead'. Cited 
become too taxing and too tiring - a possibility Nuon Chea availed himself of on the day his verdict was delivered. Defendants could be brought to that cell to follow the proceedings - the proceedings against them —in recumbent form: dozing, napping, sleeping even, while the show goes on. This way, due process is met all the while.

The guide made it clear that on site at the ECCC nutritious food was to be found to keep the defendants healthy. Barely alive war criminals seem to fare better than the many other barely alives throughout Cambodia. They appear(ed), aesthetically, to be indulged, while the many others-invisible-scrabble and struggle. But the same can be said generally, to be sure: accused war criminals within international criminal justice institutions appear quite well off compared to persons tried at the domestic level and to the population —including victims and survivors — at large, including in terms of access to health care. Retributive imbalances abound. And, certainly, international institutions would not wish to treat elderly defendants poorly, feeding them badly, and neglecting them. Those aesthetics also would be most troubling and disturbing, no?

In front of the ambulance, and across from the holding cell, stands the ECCC's medical unit. We did not ask, so we don't know exactly, but we sensed that the medical center was not for all but only for a few-as it now stands, one. All this would seem somewhat ironic in a country with a life expectancy in the mid-sixties. On an occasion, or two, the guide called it a hospital. We do not think it is a hospital, really, since when they were not (are not) doing too well the barely alive defendants end(ed) up elsewhere, in a real hospital. Infirmary is a better word, perhaps. But the accommodations for all these infirmities are not side-pieces to the ECCC building (Figure 4). Rather they are integral to the architecture of the place and the public outreach, as we experienced it, which it radiates.

The old building has multiple floors (Figure 5). The court is up a level. The stairwells and staircases have been retrofitted with wheelchair lifts. At the entrance to the courtroom one encounters a toilet. There is a piece of paper affixed to the door. It reads, 'for accused only'. The toilet is not for witnesses or victims (a sign points to other facilities elsewhere for persons other than the accused). The bathroom, the one for the accused, has moreover been modelled in the most accessible manner. The whole building, in fact, is strikingly accessible. All this progress and steps toward equality are to be welcomed. Yet the impetus, its raison d'être, remains because and for these defendants, inspired

in E. Weisband, The Macabresque - Human Violation and Hate in Genocide, Mass Atrocity, and Enemy-Making (Oxford University Press, Oxford, 2017), p. 12 (emphasis added). 


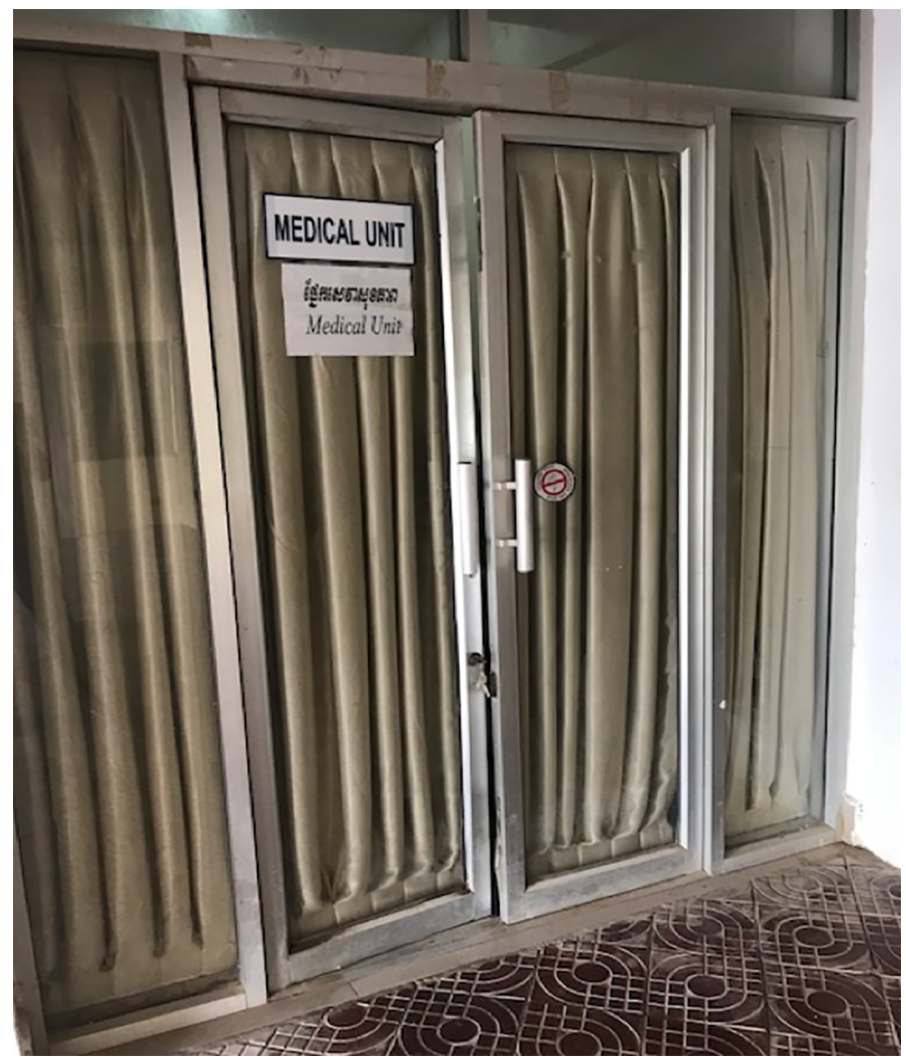

FIGURE 4 Inside the ECCC building.

by an imperative to keep them alive so as to prosecute and punish them. Indeed, perhaps, their presence in the courtroom might be an early beacon in Cambodia of the human rights of the differently abled, signaling the need to construct inclusively.

Archaeology, too, is central to Cambodia, notably the temples in the northwest: Ta Promh, Bantreay Srei, Bayon, Angkor Wat, and many more. So still for so many years and now they find themselves so busy and burgeoning, if not burdened, with the feet of so many visitors. Some, like twelfth-century Ta Promh, melt into the forests while the jungle wends about, sinuously all around, propped up at times with metallic prosthetics. The sunrise over Angkor Wat has become bucket-listed. The image is iconic. Touristically iconic, much like selfies taken at Notre Dame in Paris or the Taj Mahal in Agra. So these temples no longer are still. They endure the pedestrian pitter-patter and thereby remain enduring. But they endured beforehand, too. Despite attempts to eradicate everything, and reboot a 'Year Zero', even the Khmer Rouge embraced 


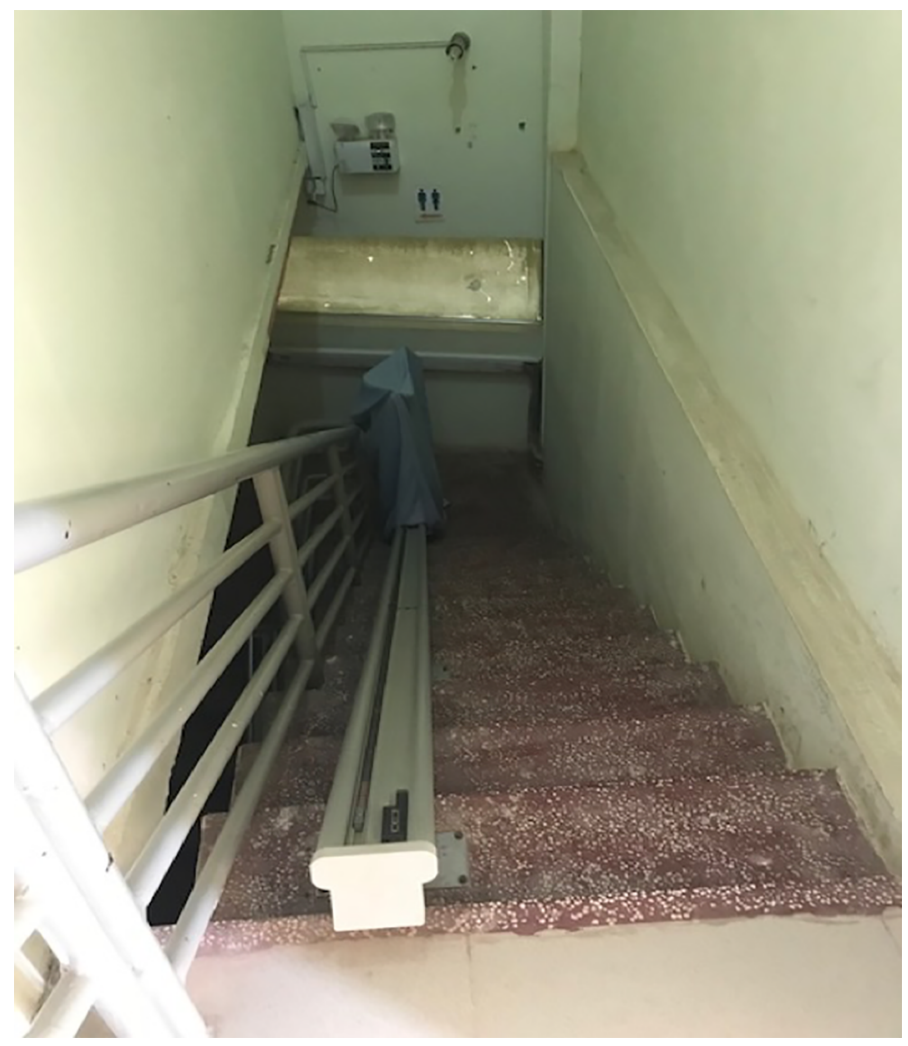

FIGURE 5 Inside the ECCC building.

their imagery. At the Killing Fields, in the little museum, a placard shows the flag of Democratic Kampuchea. The flag is bright red and festooned with a yellow image of Angkor Wat in the middle. The same image, that of Angkor Wat, flies on Cambodia's flag today. That museum, moreover, has placarded photographs of the ECCC defendants. In those photographs, selected for public display, those defendants look hardier and haler than how they look in many (most) other photographs. It seems that was a deliberate curatorial choice.

These defendants, well, they too are archaeological relics of sorts. They are to be desperately preserved in the living, if possible, in order to be prosecuted and serve as much sentence as can be eked out. Perhaps the trials help them live longer physically and mentally, because of the seemingly doting care they receive.

In a sense, and this is not a new point, trials - and the courtroom-are a form of publicity ... and it could certainly be argued (tritely) that 'there is no such thing as bad publicity'. Yes, trials can provide a platform for the expression of hatred and the condoning of atrocities; yes, trials can give perpetrators 
the opportunity to deny crimes were ever committed and to shift blame. International criminal trials, including those before the ECCC, are admittedly no exception. Yet, on a closer look, what appeared before the ECCC, whether repentant or not, were aged, unhealthy-looking individuals, some missing teeth, others hardly able to stand. Behind fairly pompous names which could trigger some form of fear and/or reverence and which, at the time of the Ângkar, denoted 'honorific seniority', ${ }^{8}$ lurked in reality very old and frail individuals. In court, Brother No. 2 (Nuon Chea) evidenced a pathetic attempt to retain a semblance of authoritative distance by wearing black glasses. If the charges against them are to trigger horror by presenting the acts they allegedly committed, well, as individuals — at the time of their trial—-they instead inspired curiosity and sometimes disdain. Assuredly, the barely alive retain agency to the very end. They bullshit and exaggerate, they jockey, they fake it, or some of it, and they become troublesome, they demand. ${ }^{9}$ They are far from ideal defendants though they may once have been ideal perpetrators.

When tried, these barely alives - who achieved fame through the perpetration of horrendous acts-do not always trigger our pity or clemency but also a form-contemptuous or not-of curiosity. Is it not as if we were looking at relics—objects from ancient times—exposed behind, and protected by, a glass window? The courtroom morphs into a museum; the judicial process becomes an act of curation. These analogies raise a series of questions, notably as regards the background and aims of the curator as well as the identity of the intended audience.

Each trial being its own exhibition by and of itself, the curator (no different than a symposium journal editor) will carefully organize it and guidemore or less leadingly - the public. The curator will decide which pieces to highlight and, in a way, which story to tell. In the courtroom, just like in a museum, the public - the 'visitors' - go from one phase to the next not by chance but because the curator has chosen a specific itinerary. Admittedly, each party at trial might be a distinct curator, with its own approach to the exhibition and with its own itinerary. The public, however, stays the same;

8 Weisband, supra note 7, p. 301.

9 In a New York Times article reporting Nuon Chea's death, the following appears: 'Mr. Nuon Chea was an exacting inmate at the special holding center attached to the tribunal, demanding a more comfortable mattress, a diet of fish and vegetables and a Western-style toilet because, according to his lawyer, the usual squat toilet of Cambodia was hard on his knees.' Seth Mydans, 'Nuon Chea, Khmer Rouge's Chief Ideologist, Dies at 93', The New York Times (4 August 2019), available online at https://www.nytimes.com/2019/o8/o4/obituaries/ nuon-chea-dead-cambodia.html (accessed 28 July 2021). 
the centerpiece - the defendant - as well. When the defendant is a barely alive his or her deliberate display can be, if not manipulative, then at least highly oriented and the role and aims of the curator(s) might be influential. On the one hand, the barely alive appearance might call for leniency towards aged individuals, who need help and care rather than condemnation for acts that happened in a far-away past. On the other hand, displaying the barely alive might facilitate their qualification as evil. The museography would here orchestrate an 'othering' process and allow for the excision of the barely alive from the community of the living. The judicial museography could ultimately further a distancing and contribute to confining atrocities to the past. This is a major theme that streams throughout this symposium-these competing aesthetics.

In this sense, there might be something generational in these trials and something of a 'cleanse', making room for the new, the fresh, the modern, the young. Prosecuting the barely alive could also be seen as symbolically cutting the umbilical cord, marking a radical detachment, with the irrational belief that the youth is totally different from the elderly, in complete ignorance or indifference to the inevitable truth that the old is the has-been young, and the young is the will-be old. Maybe the generational feature of trials is rooted in fear: fear of this truth and fear of ageing. In that sense, trials displaying living dead, and publicizing old individuals who committed evil might constitute a form of societal exorcism.

Age advances time and as their time, the time of the defendants, advances the trial process becomes rushed. Hasty and breathless, two things that law isn't supposed to be. The inevitability of death, a death that extinguishes legal process, hovers over the ECcC like a sword of Damocles.

The barely alive seep into the very core of the ECCC. They are existential to its mission. That means that the justice project it pursues also teeters and totters between life and death. The building is barely alive as its work product withers and dries up. Perhaps that building - this retrofitted, bricolaged palace of justice-shall have an afterlife. Perhaps it too shall be(come) repurposed for something else, another goal, another task, another venture-modest or grandiose, messianic or heathen, international or local. The act of prosecution ends and it is hoped something new begins in the places where prosecutions once occurred. If not, then, that building eventually itself becomes a relic, something archaeological, a temple of its time and a memorial to the fate of a faith. In this regard, it becomes a site. International criminal justice itself is obsessed with sites: atrocity sites, justice sites, reconciliation sites, commemorative sites, and cultural sites. And, as Barbora Holá and Thijs Bouwknegt set out, those sites that transitional justice emptily looks past-whether out of 
boredom, limited resources, or lack of kinetics - these may become overrun, themselves disappearing in jungles of sorts, with no prosthetics propping them up, lost amid the leaves and vines, such as the Jáchymov prison from the days of Communist Czechoslovakia, and those leaves and vines entangle to shroud moments and lull them into secrets.

Oddly, in light of all this elderliness everywhere, when we left the ECCC tour and exited the building on that hot July day we were greeted by hundreds of Cambodian school-children. They were in uniform. They chattered joyfully and clattered animatedly while eating outside at plastic tables in the open-air sitting area. We learned from our guide that they were from far away. ${ }^{10}$ They had come to the capital to visit the triad of S-21, the Killing Fields, and lastly the ECCC. For us, it was a pleasant - and perhaps reassuring — sight while we exited the site.

Some of the articles in this symposium indeed do touch on Cambodia. Stéphanie Benzaquen-Gautier's, as mentioned earlier, investigates the 1979 trial of Pol Pot,11 widely seen by the illuminati as a parody of justice, and the cremation of his body in 1998, through the lenses of performance theory, forensic aesthetics, and contemporary visual arts to investigate the role of his body as a political tool in post-transition Cambodia. Shannon Fyfe also refers to the ECCC trial of Nuon Chea to expose the defendant's 'suffering on a public stage'. Yet, and as alluded to, the other contributions focus on different geographical and legal contexts, thus revealing the global issues raised by the prosecution of the very aged.

10 See ECCC, '470 students from Tbong Khmom province visited ECCC', available online at https://www.eccc.gov.kh/en/articles/470-students-tbong-khmom-province-visited-eccc (accessed 24 July 2021).

11 Following the Vietnamese invasion of Cambodia in 1979, the successor government in Phnom Penh established a People's Revolutionary Tribunal to prosecute former Khmer Rouge leaders. This institution convicted Pol Pot and Ieng Sary in absentia and sentenced them to death. Only one of the eleven Tribunal members had legal training. The ECCC identified the Tribunal as lacking in independence and impartiality, and held that its decisions were 'incapable of producing valid legal effects'. It did so because Ieng Sary challenged his prosecution at the ECCC because of his 1979 Tribunal conviction, citing the principle of double jeopardy and the subsequent pardon he had received. The ECCC rejected this objection inter alia on the basis that the Tribunal proceedings had not been conducted in accordance with due process. See EcCc, Prosecutor v. Khieu Samphan, Nuon Chea, Ieng Sary and Ieng Thirith, Case o02-E51/15, Decision on Ieng Sary's Rule 89 Preliminary Objections (Ne Bis in Idem and Amnesty and Pardon), 3 November 2011, para. 30. 


\section{3 Scenes of Justice Between Life and Death, Running Against Time}

We initiated this journey intending to focus on defendants: geriatrics in the dock. And many of the contributions do relate to them. But along our journey we also seemed to ignite and kindle broader conversations about the passage of time, about performances, about presence and absence, about the seen and the unseen (or perhaps about the scene and the un-scene).

In her contribution on the prosecution of Radovan Karadžić and Ratko Mladić, Iva Vukušić engages precisely with the passage of time and considers the aging of the trial and the long lull (and mull) between the end of violence and the start of accountability. She posits, rooting herself in the Balkans, that delay can actually be beneficial in prosecuting leaders for atrocity crimes. While ordinarily it is assumed that the passage of time dulls memory and dries out evidence, Vukušić claims the opposite. Delay can be a friend, and not necessarily a foe, to the justice project. Delay may bring clarity, accuracy, content, confidence, and courage. Her article thus sheds new light on legalisms. So, while we intended for our project to focus on the visualities of the trial, and avoid discussions of legalisms, we here found that, when gazed upon through the lens of aesthetics, legalisms do look and seem different—refreshed even. New apertures arise to view proceduralism, clocks, and time's tick-tocks.

Some contributions examine the wrinkled lines between the living and the dead: the barely alive and the newly dead as accused in the courtroom. Yet, even here, what is seen in the courtroom may differ from what becomes telegraphed by the media outside of the courtroom. And media reports reach a far wider audience than a public access gallery, for sure. Hikmet Karcic examines in his contribution how media reports generate their own aesthetics and public stories - these bob and weave and narrate in ways that may depart from the intentions of 'international justice makers' or which may do the 'dirty work' for these justice makers in terms of discrediting the defendant. ${ }^{12}$

Some contributions revolve around the visualities of aged witnesses. Samuel Matsiko explores the role and presence of aged witnesses in the trial of former Chad dictator Hissène Habré before the Extraordinary African Chamber in

12 See also generally, K. Ristić, 'Accused War Criminals qua Perpetrators On the Visual Signification of Criminal Guilt', 2(2) Journal of Perpetrator Research (2019) 156-179. For discussion of this phenomenon within the gendered frame of women atrocity perpetrators, see M. Drumbl and S. Mouthaan, "A Hussy Who Rode on Horseback in Sexy Underwear in Front of the Prisoners': the Trials of Buchenwald's Ilse Koch', 21(2) International Criminal Law Review (2021) 280-312. 
Senegal. ${ }^{13}$ He shows how the testimonies of aged witnesses and witness-victims unveil the visualities of atrocities, here perhaps revealing another beneficial facet of the passage of time. Konstantinos Tsinas also addresses this issue and discusses Eva Kor, an elderly and very vibrantly alive Holocaust survivor who was slated to testify against Oskar Groening, the accountant of Auschwitz, in a 2015 trial in Germany. Kor appeared in court, indeed, but then proceeded to befriend Groening, embrace him, and reconcile, while complaining — with laughter, and with him-about how it feels to grow old and not have the body being able to do as it once had done, any more, the declining physicality, which led in Groening's case to his death following conviction and this reconciliation in 2018. Kor, her relationship with the other witnesses, and the imagery of the courtroom hug, is a specific case we hope to examine further in a separate publication of ours. ${ }^{14}$ For Tsinas, this dyad grounds a theory of 'communicative asymmetry' in which prosecuting shadows of their former selves may look indecent, and paradoxically unjust, as they just do not look like sinister, baleful monsters any more. An asymmetry thereby arises between intentions and effects, between the pursuit of justice and the look generated by pursuing justice. And many defendants, to be sure, may play this game: they may hype up their frailties, may guilt-trip audiences, may dramatize, may hem and haw.

Giving a different account of the use of the media than the one reported by Hikmet Karcic, Caroline Davidson shows that the press can be key in disseminating an image of convicted human rights violators as 'pobres viejitos'. In 'Of Old Men, Country Clubs, and Atrocities-The Visualities and Externalities of Detaining Elderly Human Rights Violators in Chile', Davidson explains the social/societal divide the incarceration of human rights violators has generated in Chile. Some Chileans express concerns, if not outrage, at the detention of human rights violators in Punta Peuco, a 'country club prison', rather than in ordinary places of detention. Others are moved by the 'pobres viejitos' and call for a debate on penal reform for elderly inmates.

This image of 'pobres viejitos' is admittedly not exclusive to the Chilean context. Focusing on Argentina, Lior Zylberman and Adriana Taboada hone in on the written press, both in the form of editorials and of photographs of represores taken in their prison cells, to show how it may be used to trigger what they call an 'age-impunity rhetoric' and a 'gerontological impunity'. Unveiling

13 Habré reportedly died of Covid-19, on 24 August 2021, while serving his life sentence. See ввс, 'Convicted ex-Chadian leader Hissène Habré dies at 79', available online at https:// www.bbc.com/news/world-africa-58316923 (accessed 24 August 2021).

14 See M. Drumbl and C. Fournet, 'Atrocity Then, Trial Now: The Aesthetics, Acoustics, and Visualities of Prosecuting Oskar Gröning', in M. Vormbaum (ed.), Spätverfolgung von NS-Unrecht (Springer, Berlin/Heidelberg, forthcoming). 
the performances of the convicted, Zylberman and Taboada demonstrate how 'the visual configures a certain aesthetic that provides a scaffolding for impunity and its naturalization'. In analyzing the visuality provided by photography, they explain how ' $[p]$ hotography like all images, in the same movement materializes presences and absences; that is why the photographic image is not transparent or a window to reality but a code to be interpreted.' In highlighting the tension between what we see and what we do not see, between presence and absence, they highlight the binomial seen-unseen; a binomial which could be re-spelt as scene-un-scene.

This binomial is an underlying aspect of Sofia Stolk and Renske Vos' article on admittedly the most iconic justice scene-namely, Courtroom 6oo-the happenstance space where the Nuremberg proceedings took place. Initially repurposed for an atrocity trial and now memorialized as a justice site, Stolk and Vos approach Courtroom 6oo through a particular project aimed at virtually re-creating 'the place "where it happened", and pushing the boundaries of experiencing "being there", where it happened.' They thus envisage Courtroom 600 through the aperture of another liminal state, that is, between the actual and the virtual, which is another form, perhaps, of the porousness between the living and the dead but also between seen and unseen, presence and absence. Virtuality, or reenactment, might be the only way to keep justice narratives alive once all participants in atrocity - perpetrators, victims, observers, the persecuted who also persecute-have died. Through engineering a travel back in time, virtuality also erases all traces of aging: with this project, Courtroom 600 and all its actors defy the test of time, and perhaps death itself. In that sense, virtuality could also be envisaged as an aesthetic reconstruction.

In this special issue, aesthetics-positive and negative-are also explored via a more theoretical, representational and expressive lens. The question of what the prosecution of the elderly means for the status of the elderly as full rights holders in society is particularly salient in Shannon Fyfe's and Kirsten Fisher's articles, both of which interestingly lead readers to diametrically opposed conclusions. Each scholar examines the meaning(s) of pity, mercy, vengeance, agency, and responsibility. A bridge thereby builds towards discussion of ageism, and discrimination, with Fisher making the powerful argument that actually prosecuting an enfeebled defendant for what he or she had allegedly done long ago is a sign, indeed, that the elderly are to be taken seriously in society and are rights-holders. Riffing off her brilliant work at the other edge of the age spectrum, namely with child soldiers, Fisher posits that respecting a group means holding its members accountable, while dismissing them as weak and incapable of being prosecuted leads to negligence and a brittle social inclusion. In this sense, she says that too much protectionism, too much 
sympathy, can lead to disempowerment. If we look at the current pandemic context, CoviD-19 places the respect for the elderly in the discursive frame. We fail to protect our aged co-citizens from COVID-19, and yet we prosecute them for crimes committed long ago. Alternately, perhaps, it is by confidently (and fairly) prosecuting the elderly for what they once did that we can assure that they are taken more seriously in other matters of life and death.

If Fisher opines that 'deciding not to prosecute would be a communicative disservice to the old', Fyfe takes a seemingly opposite view, arguing that individuals nearing the end of their lives 'should generally not be subjected to public trial and punishment' since the negative aesthetic experiences generated by this publicity are not justifiable. As Davidson also puts it, 'the visualities of trying and punishing the elderly are not great'. Fyfe's reflection focuses on public prosecutions and punishment, thus prompting the question of closed door trials. These would very likely breach human rights law and the right to a fair trial which presupposes a publicity of hearings. They also, as identified by Davidson, contribute to making the crimes committed less visible. In turn, they can generate a narrative of denial of the atrocities committed. If the optics of invisibility can thus have adverse effects, so can those of visibility.

In an elegant and vivid contribution, James Burnham Sedgwick unpacks the 'optical allusions' of frail perpetrators in court-shadows of their former selves - whose display might leave many observers conflicted and toying with feelings of pity and awkwardness. Sedgwick embeds Tsinas' 'communicative asymmetry' into the context of post-World War II trials of Japanese leaders in Asia. Harshly prosecuting a weak defendant may look like 'too much'. The bully is no longer a bully, so it seems unseemly to be pushing that erstwhile bully, now helpless and defeated, around. Yet, a question arises. What would it look like not to prosecute at all? What would this blank screen, or silence, represent? What about the aesthetics of 'doing nothing', and just avoiding the glaring reality that someone once was an atrocity perpetrator? This, too, is a topic that we intend to write about in a future project. After all, frail people can really hurt others; and so, too, is the case with persons who once were strong and then became weak. On this note, prosecuting the meekly aged and weakly infirm can help diminish one of international criminal law's mythologies, namely, that perpetrators of atrocity are powerful and omniscient. In reality, the meek and the weak can inflict extensive cruelties even as their own bodies become ravaged by others or merely the passage of time.

And as Aman Kumar notes in his paper about the British colonial prosecution of the Mughal Emperor Zafar, sometimes trials indeed can be bullying, and prosecutors may trump up charges, exaggerate wrongdoing, and prosecute for ulterior purposes of control and manipulation of power. Here, too, the look of such 
prosecutions may lead to the very same asymmetry, glaringly even, and in this space, perhaps, the asymmetry may serve to dissuade trials from becoming war, or oppression, conducted by other means. Alternately, as Kumar reveals was the case with Emperor Zafar's prosecution -- indeed a show trial of sorts -- 'being old' can be evoked not only as pathos (which the Emperor sought to do in his defense) but, instead, asserted by prosecutors to show disgust, contempt, and to dehumanize the accused. The elderly can be cast as befuddled, incontinent, unattractive, wrinkled, forgetful, ugly, revulsive, flaccid, and useless. Clearly, such a presentation, of the barely alive as gross and miasmic, implicates disturbing strains of ageism and discrimination, invoking Fisher's concerns. Indeed, once again, the theme drifts back to Fyfe's compelling contrast of negative and positive aesthetics and the stark differences between them in terms of energy and motivation.

Moritz Vormbaum unspools life-cycles, another unexpected theme for us, and how these 'look' in a courtroom, namely, the 'unusual' prosecution of 93-year-old Bruno Dey for Holocaust-era crimes, which occurred in Youth Court in Hamburg, because the crimes were committed when he was a 17-yearold ss member. In this case, aged witnesses were aplenty, as Vormbaum sets out, though none acted like Kor. Furthermore, the age of the defendant at the time, while dictating the visualities of the room in which he was prosecuted, did not seem to factor meaningfully into the prosecution-though his sentence of two years suspended time recognized his current frailty. And Dey apologized. Nonetheless: the 'evening of his life', as Dey described his aged place, was destroyed.

Though time is taking over, German Holocaust trials continue. ${ }^{15}$ The International Criminal Tribunal for Rwanda, itself shut down because of a 'completion strategy', nevertheless faces a slightly similar situation with the bringing into custody (after 23 years of being a fugitive) of genocide suspect Félicien Kabuga, a financier aged in his mid-eighties. ${ }^{16}$ And possible trials of the infirm, nursing home justice, pop up elsewhere and everywhere, it seems. For example, genocide and

15 See, e.g., charges brought against Irmgard F (also in juvenile court): в вС News, 'Stutthof camp: Woman, 95, accused of aiding Nazi mass murder', available online at https://www. bbc.com/news/world-europe-55953967 (accessed 19 August 2021); see also the case of Friedrich Karl Berger: ввс News, 'Friedrich Karl Berger: US deports ex-concentration camp guard to Germany', 20 February 2021, available online at https://www.bbc.com/news/worldus-canada-56140903 (accessed 19 August 2021).

16 M. Simons and N. Onishi, 'Rwandan Genocide Suspect Arrested After 23 Years on the Run', New York Times (16 May 2020), available online at https://www.nytimes.com/2020/05/16/ world/europe/france-rwanda-genocide-kabuga.html (accessed 24 July 2021). See also IRMCT, Office of the Prosecutor, 'Mechanism Fugitive Félicien Kabuga arrested today', 16 May 2020, available online at https://www.irmct.org/en/news/20-o5-22-mechanism-fugitive$\mathrm{f}_{0} \mathrm{C}_{3} \%$ Aglicien-kabuga-arrested-today (accessed 24 July 2021). On this case generally, see https://www.irmct.org/en/cases/mict-13-38 (accessed 24 July 2021). 
crimes against humanity proceedings, hibernated, against Sudanese President Al-Bashir - currently in his late-seventies - might become reawakened. In August 2021, the Sudanese government approved a draft bill allowing it to join the Rome Statute, and announced that it would transfer Al-Bashir and two other officials to the ICC. Al-Bashir's health, mental and physical, does not appear to be great. In December 2019, he had been sentenced domestically in Sudan to two years in a social reform facility on charges of corruption.

And, finally, while we sought to focus on atrocity crimes, one contribution also addresses serious criminality outside of international law definitions of core crimes and, fascinatingly, reveals some common themes. Hadar Aviram's project deals with the parole hearing of Susan Atkins, one of Charles Manson's followers, and the visuality offered by a picture of her recumbently dying in a hospital bed before the Californian parole board. This picture stands in stark contrast to those featured in Zylberman and Taboada's article: here, there is no performance on the part of the convicted criminal, no fake portraying of the criminal as a martyr, no cynical representation of the represores' bodies as territories of 'where justice exercises its violence'. All there is a very visible asymmetry between the different protagonists; an asymmetry that aptly illustrates Fyfe's argument of unjustifiable negative aesthetics.

Corporality and physicality are themes that are underlying in the majority of the contributions - and ones that will deserve further investigation. They can be approached from a multiplicity of angles in the context of our project, notably by confronting the physicality — and visibility—of the perpetrator and the absence — and invisibility — of the victim. The body of the perpetrator can take different forms: the body of the defendant as evidence of the time that has elapsed since the crimes were committed; the body of the convicted as evidence of the time spent incarcerated; the body of the fugitive as evidence of life on the run and/or of enjoyable free life; the corpse of the dead perpetrator. By contrast, the body of the victim, present or absent, can serve as evidence of the crime perpetrated and as a testimony of a life that once was.

Our journey does not conclude with this symposium. Rather, it continues, and it will soon assume the form of an edited book that will build upon this symposium but then also go well beyond, so we are excited to see where it all leads. One of our aspirations is to develop a more robust theory of trial aesthetics. We believe there is sufficient 'there there', or 'here here', to see this journal as a first step, and then a book as a second step that will even more clearly harmonize 
thinking and sooth a marked need for engagement with aesthetics, aging, and atrocity. We also hope in this context to touch upon unanswered questions, or questions not yet really posed. For example, what about the perpetrators who age - as all do-while serving their sentences? Aviram sets a wonderful table for this conversation, as she titles her contribution, but in the case of her case-study - Susan Atkins - the release never happened, was denied, and the convict dies. So, the question lingers: What does it 'look like' for a very elderly person to leave prison? What and where is that person's home? In the American film The Shawshank Redemption, two characters-Red and Brooks - travel different paths following their release after several decades in prison. Brooks cannot manage his rehabilitation job in the corner store bagging groceries, and he feel lost, so he hangs himself. Red cannot manage his job in the corner store bagging groceries, and he feels lost, so he breaches parole and travels by bus illicitly to Mexico, his guiding star a post card from Andy, who had earlier escaped from prison. Red ends up in Andy's embrace on a glorious Mexican beach and a future of calmly sanding and building boats under sunsets. So, then, we ask, what about atrocity perpetrators and the visualities of their homecomings? ${ }^{17}$

Along its path, this journey of ours was struck — as many were-by the ravages of the COVID-19 pandemic. Plans, long accepted as givens, to proceed normally, so to speak, through what then was ordinarily in-person format suddenly seemed extraordinarily unwise and, in any event, were impossible in the context of an event that united participants from so many different countries now frozen within suddenly implacable borders. So, we paused, but never stopped, and postponed, yet our spirits never flagged — nor our tenacity — and we persevered to hold the symposium virtually in February 2021. CoviD-19 was not absent from the event and is not absent from the issue. Aviram notably puts her study of the Californian parole board within the context of the Covid-19 pandemic; a context that increases the vulnerability of the prison population but that has been met with, in her words, 'disappointing solutions'. In Chile, as detailed by Davidson, the pandemic led to the adoption of the 'Covid clemency' bill, which was deemed constitutional even if it excludes human rights violators from its scope of application; an exclusion that found itself further justified by the superior conditions of detention in Punta Peuco. Perhaps paradoxically, these superior conditions ultimately 'allowed for continued confinement of human rights violators even in the pandemic'.

17 For more on homecomings, see M. Drumbl, 'Epilogue: Homecoming Kings, Queens, Jesters, and Nobodies', 28(4) International Criminal Justice Review (2018) 438-444, https://journals. sagepub.com/doi/full/10.1177/1057567718766209 (accessed 24 July 2021). 
The question of the possible release of human rights violators and war criminals in times of COvID-19 was not solely raised in Chile. At some point in the past eighteen months, it seemed that COVID-19 could re-distribute the cards with war criminals here and there pushing to be released from prison, especially aged ones, for fears of infection. ${ }^{18}$ And indeed Hissène Habré died of Covid-19 while serving his sentence. ${ }^{19}$ As for future trials of the aged, at the start of the pandemic it seemed that they might face extinction because cancelled or suspended or abandoned. Indeed, to expose an elderly defendant to the symptomatic or asymptomatic public - even to lawyers, judges, witnesses, and bailiffs — could amount to a human rights abuse of a different sort, namely, a violation of the right to life and health. Well, it might be that vaccines and masks can save it all, the operational vitality of the sites of making justice, and this, too, we shall see, these intersections between public health and public accountability. And so, in some instances it does seem that the justice-making machinery, fortified by vaccines and masks, does continue, even in the case of extremely aged defendants - such as the appeal by Khieu Samphan, the last ECCC defendant alive. That said, once again the visuals change: Samphan presents, now, in the image reproduced earlier in our introduction, not only as a convicted war criminal but also as a potential Covid-19 victim, as part of the very band of geriatrics who, if infected, likely would succumb. He looks like someone trapped in a nursing home, this judicialized infirmary. And yet we insist on prosecuting him in public, exposing him to these risks and dangers, now with the very easily transmissible Delta variant that seems to cause cases that break through our vaunted defenses of vaccines and masks and handwashings. So, now, when we see him in court, well, we see that too, that additional layer of frailty, behind the medical mask.

CoviD-19 killed so many, and was paralytic, indeed, to so many projects, but we also took it as catalytic to forging ahead, which we did. Visuals helped energize our spirits. Mainly one visual, which inspired us greatly and which we reproduce here (Figure 6). It is painted by David Hockney, in March 2020, and titled 'Do remember they can't cancel the spring'. When cancellations began to cascade, we pledged not to give up, and we did not. Here is this lovely painting of daffodils continuing to bloom and, while bracing and hunched, retain the resolve to stand tall as grey pandemia inexorably rolls in:

18 See, e.g., Association of Defence Counsel Practising Before the International Courts and Tribunals, 'ADC-ICT urges President of the UN International Residual Mechanism for Criminal Tribunals to urgently grant early or provisional release to detainees in light of the Covid-19 pandemic', 27 March 2020, available online at https://o3f4ac73-be6a-4070-8a29-4e4d17b4545d. filesusr.com/ugd/ce12e8_8305a6d5ob3a4ab88c56774co384efic.pdf (accessed 28 July 2021). 


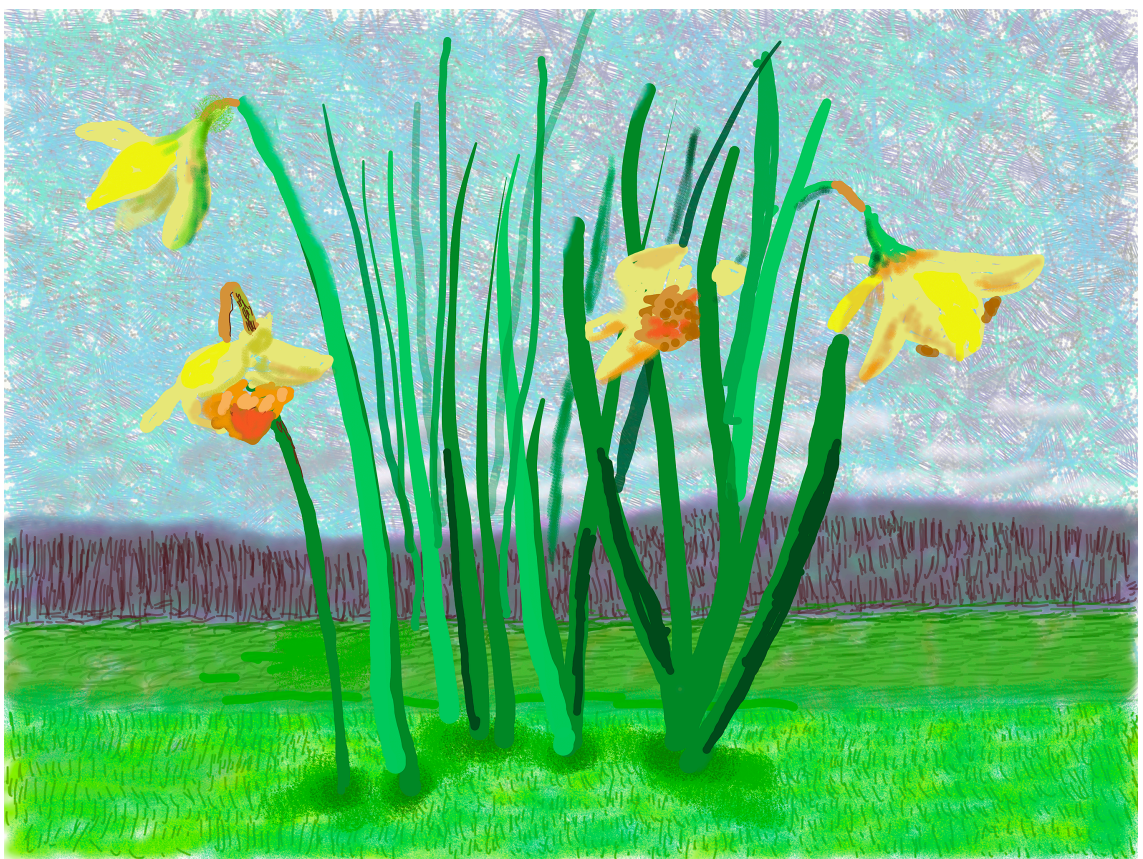

FIGURE 6 Do remember they can't cancel the spring. Credit: David Hockney, Inc.

And Hockney's words loom large, too, for us:

'The world is very, very beautiful if you look at it, but most people don't look very much, with an intensity, do they? I do.'20

So like Hockney we hope to look, intensely, at what the prosecution of the very aged looks like.

20 Martin Gayford in conversation with David Hockney, Spring Cannot be Cancelled (Thames \& Hudson, London, 2021), pp. 202-203. 